\title{
A STUDY OF HRM PRACTICES AND ORGANIZATIONAL CULTURE IN SELECTED PRIVATE SECTOR ORGANIZATIONS IN INDIA
}

\author{
Anil Kumar Singh*
}

\section{Executive summary}

The new economic environment is primarily marked by the freeing of shackles for entrepreneurship and economic growth. The "license system" has been replaced, to a great extent, by a "market system". The challenge of Human Resource Management (HRM) practices would be to create an environment of resilience, which can accommodate and assimilate successfully changes in systems, structures, technologies, methods, etc. People would have to ascribe the right meaning to the change process. India is well-equipped to succeed on global markets. It has a pool of highly educated people, a well-developed judicial system, democratic governance, an established banking industry, and fairly sophisticated and inter-linked financial markets. Knowledge industries will be at the vanguard of economic opportunity, and India will be poised to take advantage of this trend with its corpus of highly skilled people.

The changes on the market scene have necessitated the Indian industry to look inward for the development of human resources (HR). People develop themselves in a globalized scenario with new directions along with new problems and issues arising to develop new competencies to meet the changing requirements, aspirations, and problems. There are, however, some universal goods towards which all human resource management efforts should be aimed at. The emergence of Japanese human resource management has led to the concept of culture in a big way. At the organizational level, the goal of HRM is normally to have competent and motivated employees to ensure managerial effectiveness and growth of the organization. Organizations normally direct their HRM efforts towards the development of competencies and organizational culture. Organizations use mechanisms to achieve HRM goals with competent and committed employees. Organizations can achieve very little even if they have excellent technological and other resources at their command. Such an assertion gains better credibility in the context of developing countries like India, that is, typically in early growth stages in terms of economic development, and growing more rapidly than the ,traditional' developed economies of Japan, North America and

* University of Delhi, Sri Aurobindo College (dranil.singh@gmail.com).

This paper was presented at the Tenth International Conference on the topic of "UN Millennium Development Goals: Challenges and Perspectives” held in Gödöllö, Hungary, on 23-26 June, 2009. 
Europe. The countries with higher rates of growth are mostly in South East Asia, South Asia and some Latin American countries.

Research evidence shows that HR practices along with culture do affect efficiency in the organization. There are hardly any or very few studies which show a link between HRM practices and organizational culture in India. The review of literature has identified that the major chunk of research in India emanates from descriptive data and experience sharing, which does not serve certain practice-oriented concerns. There is very little systematic, empirical research in the scientific paradigm that has been carried out in the Indian HR lexicon. HR research is inspired by western models, and lacks an indigenous perspective. The review of literature on HRM practices has revealed that the most of the work done is in relation to organizational strategy.

The methodology employed a sample of 95 respondents from two private sector organizations. The questionnaire consists of 90 items, of which (1) 69 items concern HRM practices of the organization, and (2) 21 items concern organization culture.

The correlation analysis has been used to infer the relationship between variables of HRM practices and organizational culture. A healthy culture is required for utilizing and enhancing employee competencies and to develop people. This study focuses on the positive significant relationship between HRM practices and organizational culture in private sector organizations. There is a positive significant relationship between HRM practices and variables of organizational culture operationalised in terms of self-realization, status enhancement, inventive values and socio economic support.

The pressures are most likely to be felt by those who have led and managed the change process in such a volatile economic environment. HRM would have the ability to attract and retain people and this would be the key to manage this macro change-in terms of both pace and rate. Change leaders would be confronted with the need to reorient culture, thinking and paradigms. HRM as a function and as a prime mover would need to focus on this changing and emerging role with the help of organizational culture.

\section{Introduction}

The global turmoil has witnessed the growing importance of Human Resources Management (HRM) in both business and public life. The turbulent business climate brought in the wake of liberalization, globalization, changing technologies, growth in knowledge and advances in information technology is offering managers a complex and challenging situation (Davis, 1995).

Indian organizations are tending to become competitive to meet globally relevant standards. The growing emphasis on privatization has warranted a new focus in terms of result orientation, long-term strategies, consumer focus, initiative and different mindsets for internal and external communication.

The Indian business scenario is characterized by the historical rigidities arising largely out of centralized planning. Our decision-making is influenced, among other factors, by posing more a constraint rather than a facilitator. The practice of protecting Indian industries through protective tariffs and quotas for over four decades has led to a lack of global competitiveness in terms of quality of products, services and prices. 
Indians are more accustomed to thinking in terms of narrow identities like our own selves, caste, and community, regional and linguistic groups. A failing and deficient infrastructure and frustrating bureaucracy at operating levels, and the cultural and indigenous barriers added fuel to fire. Hamel and Prahalad (1991) contend that a competitive advantage is obtained if a firm can obtain and develop human resources, which enable it to learn faster and apply its learning more effectively than its rivals.

The HRM has emerged and evolved as one of the most important areas of organizational science and practice. It has not been developed in isolation, but rather in the context of industrial change and economic development. The uniqueness of the Human Resources (HR) approach requires a totally different type of attention from managers. The HR has characteristics that provide the greatest challenge as well as opportunity. A company's HR is fragile with delicate relationships, along with unpredictable contributions, and permanency is uncertain (Guest, 1991).

Wright, Smart, and McMahan, (1995) mention that the crucial inputs, among others, to an organization are its human resources. People bring to their jobs diversity of skills, needs, goals, and expectations. They are socialized into the organization through their hiring to begin with, and their continuous functioning in the organization. According to Bulla and Scott (1994), we need to ensure that the human resource requirements of an organization are identified and plans are made for satisfying those requirements.

Guest, Conway, Briner and Dickman (1996) are of the opinion that the interface between the individual and the organization is critical to full utilization of human resources. The individual and the organization establish a „psychological contract“. Individual members expect to make contributions to the organization and receive certain rewards in return. The organization provides certain rewards and expects in return certain contributions from the individual. It is at this interface between the individual and the organization that issues such as HR planning, work analysis, career development, leadership, job motivation, the appraisal-reward process, and the organizational culture become important.

The patterns of work relationships at work reflect the HRM philosophy. The practices and philosophy of HRM are perpetuated by managers who are encouraged to follow the role model of their seniors. In the process of organization socialization they internalize the values and attitudes of their leaders. The entire process is thus institutionalized (Snell, Youndt, and Wright, 1996). In general, HRM has been described as: broad and strategic; involving all managerial personnel; regarding employees as the single most important organizational asset; being proactive in its responsibilities; and having the objective of enhancing organizational performance and meeting employee needs (Poole, 1990).

\section{Organizational culture}

The idea that organizations have culture has been acknowledged since Lewin, Lippitt and White's (1939) research on creating social climate. Culture and climate are integral parts of an organization. Organizational culture refers to a system of shared meanings held by members that distinguishes one organization from other organizations (Schien, 1985). Organizational culture provides employees with a clear understanding of the way 
things are done in that organization. Organizational culture is the perceived, subjective influence of the formal system, the informal ,style' of managers and other significant environmental factors on the attitudes, beliefs, values and motivation of the people in a particular organization (Litwin and Stringer, 1968).

The concept of culture is seen as a kind of bridge between the individual and the organization. Culture performs a number of functions within an organization. It creates a distinction between one organization and another, it conveys a sense of identity for role incumbents, it facilitates the generation of commitment, and it enhances social system stability. Finally, culture sells as a sense-making and control mechanism that guides and shapes the attitudes and behaviour of employees.

Hofstede (1980) felt that cultures which are high on the long-term orientation focus on the future and hold values in the present that will not necessarily provide an immediate benefit (e.g., Japan, China), while cultures with short-term orientation (e.g., USA, Russia) are oriented toward the past and present and promote respect for tradition and for fulfilling social obligations.

The five dimensions discussed by Hofstede (1980), help us understand the potential problems of managing employees from different cultures. One interesting finding of his research was the impact of culture on a country's economic health. He found that countries with individualistic cultures were wealthier. Collectivistic cultures with high power distance were all poor. Cultures seem to affect a country's economy through their promotion of individual work ethics and incentives for individuals to increase their human capital.

Research into the link between organizational culture and effectiveness is also limited by lack of agreement about the appropriate measures of effectiveness. The current literature has its roots in the early 1980s. Deal and Kennedy (1982) and Peters and Waterman (1982) focused their attention on the strategic importance of organizational culture and stimulated interest in the topic. Kotter and Heskett (1992) expanded on this by exploring the importance of adaptability and the fit between an organization and its environment.

Peters and Waterman (1982) argued that companies with strong culture are highly successful. They argued that superior firm performance is achieved if a company moves away from a purely technical, rationalistic approach towards a more adaptive and humanistic approach.

Carroll (1983), Reynolds (1986), and Hitt and Ireland (1987) questioned the approach taken by Peters and Waterman. Owing to such results, the causal link between strong culture and performance was seriously questioned by the end of the 1980s.

Most of the studies lack a clear theoretical conception of the nature of the cultureperformance link. Siehl and Martin (1990) elaborate on this view and also suggest that culture may serve as a filter for factors that influence the effectiveness of the organization. These factors may differ between organizations. A more thorough understanding of the mechanisms at play is essential for research on the culture-performance link. Wilderom and Van den Berg (1998) found no direct significant zero-order relationship between culture and performance. 
Taking the perceived performance and managerial leadership along with HRM practices into account, Wilderom and Van den Berg (1998) did discover that a significant relationship exists between culture and performance. This finding illustrates the importance of the development of more elaborative theories on the direction and contingencies in the relation between culture and performance. Without such theories, we may draw overly simple or even misleading conclusions. In light of the above findings, it is necessary to understand the relationship between HRM practices and organizational culture.

The presumption is that more effective systems of HRM practices, which simultaneously exploit the potential for complementariness or synergies with organizational culture, lead to better performance and enhanced effectiveness. Indian organizations are embedded in Indian culture, which influences and is influenced by the economic, political and social factors, and is also subjected to global business influences. Sinha and Sinha (1994), found self-realization and inventive values as the highest form of work values in Indian culture. Organizations appreciate corporate core values of self-realization and inventive values as they encourage and recognize innovation, creativity and achievement.

\section{Review of literature}

Schuler (1992) suggests that Strategic Human Resource Management (SHRM) has many different components, including policies, culture, values and practices. Strategic business needs of an organization are influenced by its internal (which mainly consist of factors such as organizational culture and nature of business) and external characteristics (consisting of the nature and state of economy in which the organization is existing and critical success factors, i. e., opportunities and threats provided by the industry), which are influenced by HR activities.

Thornhill, Lewis, Millmore, and Saunders (2000) found a potential role for HR-centred strategies to be used to change or realign the culture of an organization. An organization can change its culture through its recruitment strategy of replacing managers with those from outside, restructuring the organization, downsizing the workforce, training programmes, new reward strategies and performance management to alter employee behaviours or reinforce emergent ones. After the economic liberalization, Indian organizations were under pressure to change from low-cost, indigenous, less efficient and outdated technology to high-cost modern technology and prepare people to use it. This was done to develop and maintain their competitive edge in the larger business environment (Khan, 1999).

The potential value of the employees is to be increased by collectively enhancing and linking their skills and capabilities in tune with the contemporary requirements of the market, and to be faster than the competitors. The success of the HRM will be determined by its ability to harness the intelligence and spirit of people by creating a learning climate.

Indian organizations normally direct their HRM efforts towards the development of competencies, culture and effectiveness among employees individually or in groups 
(Singh, 2003). Organizations may use many mechanisms to achieve their HRM goals as without competent and committed employees, an organization can achieve very little even it has excellent technological and other resources at its command. Such an assertion gains better credibility in the context of developing countries like India, that is, typically in early growth stages in terms of economic development and growing more rapidly than the ,traditional' developed economies of Japan, North America and Europe. This also includes most South East Asian, South Asian and some Latin American countries.

Selection in organizations is based on non-job related criteria like attractiveness, goal orientation, and interpersonal skills: a general lack of concern for value congruence (Prakash, 1994). The dominant emphasis has been on the universal practice of identifying and improving on existing performance strategies. This practice would require a complete reversal where congruencies of values should find a place in selection and training. Only then would it possible to achieve linkages with the values of the wider socio-cultural context in India. In order to make an organization effective, the values of the society and the cultural milieu should be synthesised with those of the organization and its functioning.

Fombrun, Tichy, and Devanna (1984) expanded these premises and developed the model of SHRM, which emphasises a 'tight fit' between the organizational strategy, organizational structure and HR system. Political, economic and cultural forces are responsible for an organization's mission and strategy. This explains these causal relations, which form the 'tight fit' between strategy, organization structure and HR polices and practices. On the basis of mission and strategy, the shape of organization is structured, i.e., people are organized to carry out different tasks to achieve the organization's mission.

Hendry and Pettigrew (1992) propose that a number of internal factors such as the organizational culture, structure (positioning of HR), leadership, level of technology employed and business output directly contribute to forming the contents of HRM.

HRM could be seen as a menu of strategic choices to be made by human resource executives in order to promote the most effective 'role behaviours' that are consistent with the organization's strategy and aligned with each other (Sparrow and Hilltrop, 1994).

\section{The present study}

The present study is to examine the relationship between HRM practices and organizational culture. To this end, HRM practices are viewed in terms of planning, recruitment, selection, training and development, performance evaluation, career management and rewards.

Organizational culture is viewed in terms of self-realization, status enhancement, inventive values and socio-economic support. Self-realization consists of values such as achievement, ability utilization, advancement, aesthetics, personal development, and peace of mind. Status enhancement, one of the variables of organizational culture, consists of values of altruism, authority, physical activity, and prestige. Inventive values, another variable of organizational culture, consists of values of autonomy, creativity, 
lifestyles, risk-taking, and variety. Socio-economic support consists of work values of social relationship and interaction, comforts, dependency, good working condition and economic gains. The self-realization and inventive values give inner satisfaction to a person while performing a job in an organization. The variables of status enhancement and socio-economic support are extrinsic values, which are required in the Indian environment. Indian society and developing societies are ridden with insecurities and lack of resources and people generally have a history of failures. Fear of failure leads to giving importance to socio-economic support and lack of resources lends too much importance to status enhancement (Sinha, 1990).

The idea that individuals are capable of development rests on the conviction that people are important and their involvement is necessary for an organization to be effective. This conviction is translated into practice through a variety of programs that facilitate individual development and lead to better adjustment with the environment.

In a growing economy, the emergence of the new organization and shift in the HRM paradigm have necessitated a review of the skills, roles and competencies of the 'new' HR managers (Ulrich, 1997); in this new era, HRM has evolved in the context of the globalized economic environment. As such, it represents a response to the dramatic and continuous change that globalization has had on society and the world of work. Those who will man the HRM will undergo a change in roles. It will be necessary to inculcate in employees the required new skills, competencies and motivation (Dyer jr., 1999).

The understanding of HRM practices would require a comparative study of practices in the organizations. The relationship between HRM practices and organizational culture among private sector organizations is studied. This paper also studies similarities and differences in HRM practices and organizational culture between two different organizations in the private sector.

\section{Objectives of the study}

1. To investigate the various HRM practices, i.e., planning, recruitment, selection, performance evaluation, training and development, career management and rewards at the managerial levels in private sector organizations.

2. To study and examine the relationships between various aspects of HRM practices and organizational culture.

3. To find whether there is any difference in the organizational cultures of the two organizations under study.

\section{Hypothesis of the study}

\section{Hypothesis 1}

HRM practices will be positively significantly related to organizational culture. This hypothesis is further broken down into sub-hypotheses. 


\section{Hypothesis 1a:}

Planning (one of the dimensions of HRM practices) is positively significantly related to the dimensions of organizational culture, namely self-realization, status enhancement, inventive values and socio-economic support.

\section{Hypothesis $1 b$ :}

Recruitment (one of the dimensions of HRM practices) is positively significantly related to the dimensions of organizational culture, namely self-realization, status enhancement, inventive values and socio-economic support.

\section{Hypothesis 1c:}

Selection (one of the dimensions of HRM practices) is positively significantly related to the dimensions of organizational culture, namely self-realization, status enhancement, inventive values and socio-economic support.

\section{Hypothesis 1d:}

Training and development (one of the dimensions of HRM practices) is positively significantly related to the dimensions of organizational culture, namely self-realization, status enhancement, inventive values and socio-economic support.

\section{Hypothesis 1e:}

Performance evaluation (one of the dimensions of HRM practices) is positively significantly related to the dimensions of organizational culture, namely self-realization, status enhancement, inventive values and socio-economic support.

\section{Hypothesis 1f:}

Career management (one of the dimensions of HRM practices) is positively significantly related to the dimensions of organizational culture, namely self-realization, status enhancement, inventive values and socio-economic support.

\section{Hypothesis 1g:}

Rewards (one of the dimensions of HRM practices) are positively significantly related to the dimensions of organizational culture, namely self-realization, status enhancement, inventive values and socio-economic support.

\section{Method}

This study is based on a sample of managers from two different private organizations. At the time of selection of companies, both were profit-making organizations. The data was collected personally by the researcher and also by mail using convenience sampling with an assurance that information obtained would be kept confidential. The sample was obtained from all the management levels, but most of the respondents were from middle-level management, with an assumption that they would possess an accurate and comprehensive perception of HRM practices being employed. The sample included all departments such as production, marketing, finance, HRM, etc. The sole purpose of this sampling was to get an honest picture of HRM practices of the organization; out of 150 questionnaires distributed, 95 computed questionnaires were used for the final analysis. 
A bird's-eye view of the sample distribution is as shown below:
Organization A:
$(\mathrm{N}-41)$
Organization B:
$(\mathrm{N}-54)$

\section{Description of the questionnaire}

The first part of the questionnaire consists of the information about the personal profile of the respondent.

The second part of questionnaire consist of 90 items, which are divided into two parts:

(1) 69 items concern HRM practices of the organization, and

(2) 21 items concern organizational culture.

For the purpose of measuring Human Resource Management practices, the questionnaire developed by Judith R. Gorden (1986) was used. This questionnaire was standardized and the split-half reliability was calculated to be 0.81 . The HRM practices questionnaire consisted of 69 items.

The questionnaire used for measuring organizational culture was developed by Super and Nevill (1986) and new variables were added as per the Indian requirement by (Sinha 1982a and 1990). The items in the questionnaire belonged to four super-ordinate factors. Super and Nevill (1986) considered it as a component of work salience. The values were defined as the 'objectives that one seeks to attain to satisfy a need' (Super, 1970). However, the difference in the conceptualization of the role of value expectations did not deter the author from taking advantage of the groundwork done by the Work Importance Study (WIS) group. The group thoroughly reviewed the literature on values in about a dozen countries, discussed its representative nature, and drafted a list of twenty-one values. Of the twenty-one values, the first eighteen were considered usable by all WIS group members. The last three were optional, and the members were encouraged to replace them with culture-specific values. Sinha (1982a) identified the following three as typical values in the Indian culture (with the sample statements in parentheses):

19. Peace of mind (Work at a place where I can have peace of mind)

20. Comforts of life (Have a comfortable life).

21. Dependency (Work at a place where I can seek help from others in personal matters)

\section{Organizations under study}

\section{Organization A}

Organization A is India's largest private sector enterprise in the area of electrical engineering. The company has approximately 10,000 highly skilled dedicated technicians, engineers and managers. This organization has been producing fans, household appliances and lighting systems for the last 50 years.

In its endeavour to achieve excellence in the quality of its products and services, the focus on the customers remains unwavering. The TQM voyage that the company 
has embarked on continues to improve performance and competitiveness at all levels. The KAIZEN philosophy is being practiced throughout the company to reduce cycle time, improve productivity and quality, and eliminate waste. More than $90 \%$ of the employees have been exposed to TQM awareness programs. In the near future, the organization's efforts will be focused on taking up HRM pursuits to improve functional skills and strengthen emotional ties between the organization and its employees.

\section{Organization B}

Organization B has a Personnel Department and there is no change in nomenclature. The managerial staff and workers are provided with housing, education, free electricity, and water. Organization B has progressive welfare practices for employees and their families. Trust and confidence between employee and employer are built on personalized relationships. Organization B provides a way of life to the human resources it has acquired and developed to achieve the personal and organizational goals. The way of life in the organization has created a culture, which leads to effective utilization of human resources. Company B has one formal HR Manager. The functions of performance evaluation, rewards, planning, recruitment, and selection and training are performed by its Personnel Department. There is no formal career management scheme.

\section{Results and discussion}

As a result of this study, it was found that a positive correlation between HRM practices and organizational culture exists. HRM practices (namely planning, recruitment, selection, training and development, performance evaluation, career management, and rewards) and organizational culture (self-realization, status enhancement, inventive values and socio-economic support) were significantly positive. The study of culture indicated that individual values play an important role in determining how well an individual fits into the organizational context (Rousseau, 1990). Besides, many researchers have conceptualized and measured values at the individual level (Katzu, 1986; Prakash, 1982; Rokeach, 1973; Sinha, 1990) in their attempts to understand organizational culture.

This study was conducted at a time when Indian organizations were facing a very different competitive scenario compared to the past. They were facing competition from MNCs in the new liberal and global economy on the domestic markets. The competition was in terms of reduced cost, improved quality of products and better services. These environmental constraints placed more pressure on managers. More often than not, these concerns were looming large on the horizons of Indian organizations. The findings have bearing in this context. 
Table 1

Correlations between HRM practices and the dimensions of organizational culture

\begin{tabular}{|c|c|c|c|c|}
\hline Variables & $\begin{array}{l}\text { Self- } \\
\text { realization }\end{array}$ & $\begin{array}{c}\text { Status } \\
\text { enhancement }\end{array}$ & $\begin{array}{l}\text { Inventive } \\
\text { values }\end{array}$ & $\begin{array}{l}\text { Socio-economic } \\
\text { support }\end{array}$ \\
\hline Planning & $.40^{* *}$ & .23 & $.44^{\star *}$ & .17 \\
\hline Recruitment & $.45^{\star \star}$ & $.38^{\star *}$ & $.54^{\star \star}$ & .20 \\
\hline Selection & $.56^{* *}$ & $.57^{\star \star}$ & $.44^{\star *}$ & $.44^{\star \star}$ \\
\hline Performance evaluation & $.52^{* *}$ & $.30^{\star}$ & $.47^{\star \star}$ & $.26^{*}$ \\
\hline Training and development & $.50^{\star *}$ & $.33^{\star \star}$ & $.52^{\star \star}$ & $.31^{*}$ \\
\hline Career management & $.62^{\star *}$ & $.48^{\star \star}$ & $.51^{\star *}$ & $.45^{\star \star}$ \\
\hline Rewards & $.62^{* *}$ & $.57^{* *}$ & $.63^{* *}$ & $.26^{*}$ \\
\hline
\end{tabular}

Number of cases: 95; 1-tailed significance *-- .01 **--- .001

Managers across organizations in the private sector strongly endorsed self-realization (one of the variables of culture), which was significantly correlated to almost all HRM practices. These are planning, recruitment, selection, performance evaluation, training and development, career management, and rewards. While organizations find themselves in worldwide competition, most of the individuals are striving for achievement, ability utilization, advancement, aesthetics, personal development, and peace of mind. Realization or anticipation of realization of the values has resulted in better performance. Self-realization encourages people to satisfy their achievement needs in the work situation (Super and Nevill, 1986; Sinha, 1990). Self-realization in India came quite close to self-actualization in Spain.

Status enhancement was strongly related to HR practices in private sector organizations. The values loaded on this factor are authority, altruism, prestige and physical activities. The desire for authority, altruism, prestige and physical activity has a positive impact on the performance of managers. Managers developed a positive attitude towards their work and contributed significantly to self-realization and status enhancement, which were the most valued factors in India.

Recruitment, selection, and performance evaluation, training and development, career management, and rewards turned out to be strongly correlated to status enhancement in the private sector. Selection based on planning along with proper recruitment leads to status enhancement. Rewards (financial and non-financial) were strongly related to status enhancement. Performance evaluation (one of the HRM practices) was strong related to status enhancement. Performance evaluation served as a key input for administering formal organizational rewards, career growth and a tool of punishment (Cummings, 1973). Managers working in the organizations were in an excellent position to analyze newcomers' skills and abilities and to provide feedback (House, 1995). As a purveyor of organizational expectations, performance evaluation was critical. Through the evaluation process, those working in the organization were aware of how well they were meeting their task and role demands (Asford and Cummings, 1983; Nelson, 1990). Clear rewards are the hallmark of an organization that effectively socializes newcomers. In addition to their readily apparent value, the rewards provide 
challenging assignments, promotions and salary increases, etc., which give encouragement that provide status enhancement for managers (Chatman, 1991).

Rewards were also found to be strongly related to inventive values in private sector organizations. Those working in the organizations with desired values of risk-taking, variety, autonomy, lifestyle and creativity were rewarded. Rewards encourage people to be more creative, have variety and autonomy in their work life along with risk-taking and help to chalk out one's own lifestyle in the organization. Similarly, training and development in private sector organizations were strongly correlated to inventive values. So, rewards and training and development in the private sector affect both individual esteem and lifestyle significantly. Managers have developed to take on a variety of tasks in order to perform at an optimum level. Managers in the organization have developed to be autonomous and chalk out their own lifestyles to be more effective in the job. This also means employees will expect organizations to offer them opportunities to develop a portfolio of skills that enhances their marketability. Thus, organizations will have to provide work assignments and learning opportunities that allow for challenge and growth and self-development (Maurer and Tarulli, 1994).

Socio-economic support consists of social relationships and interaction, comforts, dependency, good working conditions and economic gains. Managers were indifferent and did not care much for social interactions and relationships, whereas Indian managers held significant value expectations concerning economic gains, good working conditions and comforts.

HR practices were significantly related to socio-economic support in the private sector. Through planning, recruitment and selection practices, newcomers with stronger systems of support report fewer adverse psychological outcomes related to job performance than do those with less support. Quality relationships with organizational insiders can even help newcomers to overcome the negative effects of unmet expectations (Major, Kozlowski, Chao, and Gardner, 1995). Interacting with enthusiastic newcomers may be good for insiders' attitude and morale. The study also found a relationship between career management and socio-economic support. People working in the organizations look for career management that will give them the breadth of experience that seems to be needed now, and start looking down on the in-depth expertise of the command-centred manager.

So, a shift in culture happens, not because people have changed, but because their beliefs about what they have to do to get ahead have changed (Gunz, Hung, 2000). Rewards were strongly related to socio-economic support in private sector organizations. Litwin, Bray and Brooke (1996) felt that the nature of rewards is the key determinant of how effective they are. Managers who emphasized recognition and encouragement were more effective in shaping the culture of the organization or targeted results. The reason could be that managers working in the private organizations are experiencing a tremendous amount of change around them, thereby realizing that socioeconomic well-being will provide them with stability in a fast changing environment. Furthermore, evidence from literature found the contention that similar work experiences result in uniformity of culture characteristics (Schein, 1987). 
Rewards (one of the HRM practices) were strongly related to all the variables of culture in private sector organizations. There is hardly any difference between the two organizations when it comes to practicing rewards and training and development. People within the organizations are either rewarded or trained for acting in accordance with the dominant values of the organizations in India. Although this sample is not large enough to generalize the results, still rewards send clear and consistent signals about desired values and norms expected from people working in the organizations (Sethia and Van Galinow, 1985).

The perception of the respondents from both private sector organizations were compared and it was found that there was a statistically significant difference in the variable of socio-economic support between the two organizations, as shown in the table. This means employees in organization A perceived it in a better manner in comparison to their counterparts in organization B. Prakash (1994) felt that Indian organizations are congruent with their cultural surroundings (which is marked by diversities and paradoxes). There is a need to use multiple perspectives at different levels of analysis such as society, organization, management and the individual. It is important that organizations continue to grow and evolve newer perspectives in terms of their values and redefine their linkages with the society.

Such findings provide support that market economies have the inevitable consequences of rendering organizations competitive. Newman (1972) predicted that the Western work relationships are likely to appear to a great extent in Indian organizations as well. That is, employees in the organizations are likely to become achievement-oriented. There is a struggle for survival, where no one can afford to ignore an opportunity to get optimum results. As one moves higher on the hierarchical ladder of an organization, the individualistic orientation becomes stronger. The correlation analysis between dimensions of HRM practices and dimensions of culture shows that HRM practices do affect the culture of the organization. Ulrich and Lafasto (1995) felt that HRM practices provide information and shape behaviour and experiences of employees.

Thus hypotheses H1a, H1b, H1c, H1 d, H1 e, H1 fand H1 g are validated.

\section{Conclusions}

This paper has shown a significant, positive and meaningful relationship between HRM practices and organizational culture. HRM practices become the means whereby organizational culture is created and sustained. Designing new culture requires that HRM professionals are ahead of the cultural change curve with innovative and exciting HRM practices. HRM has been proposed by others to be a potentially powerful lever for shaping and changing the culture of an organization to make the organization more effective (Schien, 1983; Ulrich, 1997).

This is a study of HRM practices in two large private sector organizations in India. HRM practices differ between the private sector organizations. This variation provides support to the fact that the adoption of HRM practices is contingent on the specific requirements of each organization (Schuler and Jackson, 1981). There is a significant 
difference between the socio-economic support variable in organizations A and B. One finds no significant difference in the other three variables of organizational culture in private sector organizations, i.e., self-realization, status enhancement and inventive values.

The results developed through inferential analysis to measure differences among the variables of HRM practices and organizational culture in private sector organizations are as follows:

1. The two private sector organizations showed that the perceived mean of organization A was higher for all HRM practices.

2. The comparison of the dimension of organizational culture in the two private sector organizations showed that employees of organization A perceived the socio-economic support more than those in organization B.

3. It is evident that organization A showed relatively better perception of planning, recruitment processes, selection, performance evaluation and career management aspects of HRM practices in comparison to organization B.

4. There is no significant difference between organization $A$ and organization $B$ in training and development and rewards as per the response of the respondents.

5. Planning, recruitment, selection, training and development, performance evaluation, career management and rewards are significantly correlated with all the dimensions of organizational culture.

\section{References}

ASHFORD, S. J.; CUMMINGS, L. L. 1983. Feedback as an individual resource: Personal strategies of creating information. Organizational Behavior and Human Relations. 32.

BULLA, D. N.; SCOTT. 1994. Manpower requirements forecasting: a case example, in Human.

CARROLL, D. T. 1983. A disappointing search for excellence. Harvard Business Review. 1983, vol. 61, no. 6, s. 78-88.

CHATMAN, J. A. 1991. Matching people and organizations: Selection and socialization in public accounting firms. Administrative Science Quarterly. 1991, vol. 36, s. 459-484.

CUMMINGS, L. L. 1973. A field experimental study of the effects of two performance appraisal systems. Personnel Psychology. 1973, vol. 26, s. 489-502.

GUEST, D.; CONWAY, N.; BRINER, R.; DICKMAN, M. 1996. The state of psychological contract in employment: Issues in people management. London : Institute of Personnel and Development, 1996.

DAVIS, P. 1995. About time: Einstein's unfinished revolution. New York : Simon; Schuster, 1995.

FOMBRUN, C. J.; TICHY, N. M.; DEVANNA, M. A. 1984. Strategic human resource management. New York : Wiley, 1984.

GIBB DYER Jr., W. 1999. Training human resource champions for the twenty-first century. Human Resource Management. 1999, vol. 38, no. 2.

GORDEN, J. R. 1996. Human Resource management. Boston: Allyn and Bacon, 1996.

GUEST, D. E. 1991. Personnel Management: The end of Orthodoxy? British Journal of Industrial Relations. 1991, vol. 3, s. 137-156.

HAMEL, G.; PRAHALAD, C. K. 1991. Strategic intent. Harvard Business Review. 1991, May-June, S. 63-76.

HENDRY, C.; PETTIGREW, A. M. 1992. Patterns of strategic change in the development of human resource management. British Journal of Management. 1992, vol. 3, s. 137-156.

HITT, M. A.; IRELAND, R. D. 1987. Peters and waterman revisited: the unended quest for excellence. 
Academy of management executive. 1987, vol. 1, no. 2, s. 91-98.

HOFSTEDE, G. 1980a. Motivation, leadership, and organization: Do American theories apply abroad? Organization Dynamics. 1980, vol. 9, no. 1, s. 42-58.

HUGH, G. 2000. Organizational cultures and careers. In ASKANASY, N. M.; WILDEROM, C. P. M.; PETERSON, M. F. (eds.). Handbook of culture and climate. California : Sage publications, 2000.

HUNT, J. G. 1991. Leadership: A new synthesis. Newbury Park, CA : Sage, 1991.

KANTER, R. M. 1984. The change masters: Corporate entrepreneurs at work. London : George Allen \& Unwin, 1984.

KATZU, P. 1986. Certain factors related to member integration in a multinational organization. [Unpublished Doctoral Dissertation]. University of Allahabad, India.

KHAN, S. A. 1999. Building organizational learning capability. Indian Journal of Industrial relations. 1999, vol. 35, no. 2, July.

LEWIN, K.; LIPPITT, R.; White, R. K. 1939. Patterns of aggressive behavior in experimentally created "social climates". Journal of social psychology. 1939, vol. 10, s. 270-299.

LITWIN, G. H.; STRINGER, R. A. 1968. Motivation and organizational climate. Boston : Harvard Business School press, 1968.

LITWIN, G. H.; BRAY, J.; BROOKE, K. L. 1996. Mobilizing the organization: Bringing strategy to life. Englewood Cliffs, NJ : Prentice hall, 1996.

MAJOR, D. A.; KOZLOWSKI, S. W. J.; CHAO, G. T.; GARDNER, P. D. 1995. A longitudinal investigation of newcomer expectations, early socialization outcomes, and the moderating effects of role development factors. Journal of Applied Psychology. 1995, vol. 80, s. 418-431.

MAURER, T. J.; TARULLI, B. A. 1994. Investigation of perceived environment, perceived outcome, and person variables in relationship to voluntary development activity by employees. Journal of Applied Psychology. 1994, vol. 79, s. 3-14.

NEWMAN, W. 1972. Cultural assumptions underlying U.S. Management concepts. In MASSIE, J. L.; LUYTZES, J. (eds.). Management in International context, New York : Harper \& Row, 1972.

PETERS, T. J.; WATERMAN, R. H. 1982. In search of excellence: Lessons from America's best-run companies. New York: Harper \& Row, 1982.

POOLE, M. 1990. Editorial: HRM in an international perspective. International Journal of Human Resource Management. 1990, vol. 1, no. 1, s. 1-15.

PRAKASH, A. 1982. A study of organisational socialisation of industrial worker. [Unpublished Doctoral Thesis]. University of Allahabad, India.

PRAKASH, A. 1994. Organizational functioning and values in the Indian context. In HENERY, S. R.; SINHA, D.; HONG, N. S. (eds.). Effective organizations and social values. New Delhi : Sage, 1994.

REYNOLDS, P. D. 1986. Organizational culture as related to industry, position and performance: A preliminary report. Journal of Management Studies. 1986, vol. 23, s. 333-345.

ROKEACH, M. 1973. The nature of human values. New York : Free Press, 1973.

ROUSSEAU, D. M. 1990. Quantitative assessment of organizational culture: The case of multiple measures. In SCHNEIDER, B. (ed.) Organizational climate and culture. San Francisco : Jossey-Bass, 1990.

SCHEIN, E. H. 1983. The role of the founder in creating organizational culture. Organizational Dynamics. 1983, vol. 12, no. 1, s. 13-28.

SCHEIN, E. H. 1985. Organizational culture and leadership: A dynamic view. San Francisco : JosseyBass, 1985.

SCHEIN, E. H. 1987. The clinical perspective in fieldwork. Newbury Park, CA : Sage, 1987.

SETHIA, N. A.; Van GLINOW, M. A. 1985. Arriving at four cultures by managing the reward system. In KILMANN, R. H.; SAXTON, M. J.; SERPA, R; Associates (eds.). Gaining control of the corporate culture. San Francisco : Jassey-Bass, 1985.

SIEHL, C.; MARTIN, J. 1990. Organizational culture: A key to financial performance? In SCHNEIDER, B. (ed.). Organizational climate and culture. San Francisco : Jossey-Bass, 1990

SINGH, K. 2003. Strategic HR orientation and firm performance in India. International. Journal of Human Resource Management. 2003, vol. 14, no. 7, s. 530-554. 
SINHA, J. B. P.; SINHA, D. 1994. Role of social values in Indian organizations In KAO, H. S. R.; SINHA, D.; NG SEK-HONG (eds.). Effective organizations and social values. New Delhi : Sage, 1994.

SINHA, J. B. P. 1982a. The Hindu (Indian) identity. Dynamic Psychiatry. 1982, vol.15, s. $148-160$.

SINHA, J. B. P. 1982b. Power structure, perceptual fame and behavioural studies in dyadic relationship. In RATH, R. N.; ASTHANA, H. S.; SINHA, D.; SINHA, J. B. P. (eds.). Diversity and Unity in Crosscultural Psychology. Lisse (The Netherlands) : Swets \& Zetlinger, s. 308-315.

SINHA, J. B. P. 1990. Work culture in the Indian context. New Delhi : Sage, 1990.

SINHA, J. B. P. 1987. The clinical perspective in the field work. Newbury Park, CA : Sage, 1987.

SPARROW, P. R.; HILTROP, J-M. 1994. European Human Resource Management in Transition. London : Prentice Hall, 1994.

SUPER, D. E. 1970. Work Values inventory. Chicago : Riverside, 1970.

SUPER, D. E.; NEVILL, D. D. 1986. The Salience Inventory: Theory, Applications and Research. Palo Alto, CA : Consulting psychologists press, 1986.

THORNHILL, A.; LEWIS, P.; MILLMORE, M.; SAUNDERS, M. 2000. A Human Resource Strategy Approach: Managing Change. Harlow : Pearson Education, 2000.

ULRICH, D.; LAFASTO, F. 1995. Organizational culture and human resource management. In FARRIS, G. R.; ROSEN, S. D.; BARNUM, D. T. (eds.). Handbook of human resource management. Oxford : Blackwell Publishers, 1995.

ULRICH, D. 1997. Human Resource champions. Boston : Howard Business School Press, 1997

WARD, D.; BECHET, T. P.; TRIPP, R. 1994. (eds.). Human Resource Forecasting and Modeling. New York : Human Resource Planning Society, 1994.

WILDEROM, C. P. M.; Van den BERG, P. T. 1998. A test of leadership culture performance model within a large Dutch financial organization. Paper presented in the annual meeting of the Academy of Management, San Diego, CA.

WRIGHT, P. M.; SMART, D. L.; McMAHAN, G. C. 1995. Matches between human resources and strategy among NCAA basketball teams. Academy of Management Journal. 1995, vol. 38, s. 1052-1074.

\section{A STUDY OF HRM PRACTICES AND ORGANIZATIONAL CULTURE IN SELECTED PRIVATE SECTOR ORGANIZATIONS IN INDIA}

Abstract: This paper examined the relationship between HRM practices and organizational culture in private sector organizations operating in India. Organizational culture has developed in the Indian environment along with global work values. This study is based on a survey of 95 respondents working in two private sector organizations. Although the HRM practices in these organizations differ a lot, there is a significant relationship between HRM practices and organizational culture.

Keywords: Human Resource Management; Organizational culture

JEL Classification: Z1 
ANNEX I

Table 1

Comparison of two private sector organizations based on the dimensions of HRM practices

\begin{tabular}{|l|c|c|c|c|c|c|}
\hline & \multicolumn{3}{|c|}{ A } & \multicolumn{3}{c|}{ B } \\
\hline Variables & Total & Mean & S.D. & Mean & S.D. & t-value \\
\hline Planning & 50 & 31.46 & 6.96 & 28.44 & 3.65 & $2.73^{*}$ \\
\hline Recruitment & 45 & 27.68 & 5.23 & 24.56 & 3.85 & $3.36^{\star *}$ \\
\hline Selection & 30 & 20.39 & 2.90 & 18.13 & 3.37 & $3.44^{\star *}$ \\
\hline Performance evaluation & 65 & 42.59 & 5.32 & 37.98 & 5.01 & $4.32^{* *}$ \\
\hline Training \& development & 45 & 30.05 & 3.62 & 29.30 & 4.69 & 0.85 \\
\hline Career management & 50 & 25.07 & 5.41 & 21.72 & 4.34 & $3.35^{* *}$ \\
\hline Rewards & 60 & 34.83 & 6.78 & 34.17 & 6.14 & 0.50 \\
\hline
\end{tabular}

${ }^{* *} \mathrm{p}<.01$

ANNEX II

Table 2

Comparisons of two private sector organizations based on the dimensions of vulture

\begin{tabular}{|l|c|c|c|c|c|}
\hline & \multicolumn{5}{|c|}{ A B } \\
\hline Variables & Mean & S.D. & Mean & S.D. & t-value \\
\hline Self-realization & 22.29 & 3.30 & 22.41 & 4.25 & -0.14 \\
\hline Status enhancement & 12.66 & 1.65 & 11.87 & 3.20 & 1.44 \\
\hline Inventive values & 14.20 & 1.95 & 14.63 & 2.72 & -0.87 \\
\hline Socio-economic support & 21.10 & 3.02 & 18.83 & 3.70 & $3.20^{\star \star}$ \\
\hline
\end{tabular}

${ }^{* *} p<.01$ 